\title{
Pelatihan Pola Ritme Sebagai Strategi Peningkatan Kualitas Pembalajaran Mata Kuliah Instrumen Gitar di Jurusan Musik FSP ISI Yogyakarta
}

\author{
Kustap $^{1}$ dan Ikhsan Lubis ${ }^{2}$ \\ 1,2,Jurusan Musik FSP Institut Seni Indonesia Yogyakarta
}

\begin{abstract}
Rhythm pattern is the main musical element that is directly related to the movement of time in music, where time is always moving and regulating musical stability. Rhythm patterns really determine the accuracy of counts in a single guitar game, and play guitar ensembles. Rhythm patterns are research material objects while the rime training process in learning guitar instrument subjects is a formal object. The method used in this study is a qualitative method and class action with the technique of collecting triangulation data, while the data analysis process uses an interactive model. The results obtained from this study are the rhythmic pattern training strategies that are tailored to the signs of sukat that are in the material in the form of songs that will be trained with guitar instruments.
\end{abstract}

Keywords: Rhythm pattern; training; learning; guitar

\begin{abstract}
Abstrak
Pola ritme merupakan elemen musik utama yang berkaitan langsung dengan gerakan waktu dalam musik, di mana waktu selalu bergerak dan mengatur kestabilan rasa musikal. Pola ritme sangat mentukan ketepatan hitungan dalam permainan gitar tunggal, dan bermain anasambel gitar. Pola ritme merukan objek material penelitian sedangkan proses pelatihan pola rime dalam pembelajaran mata kuliah instrumen gitar merupakan objek formal. Metode yang digunakan dalam penelitian ini adalah metode kualitatif dan tindakan kelas dengan teknik pengupulan data triangulasi, sedangkan proses analisis data menggunakan model interaktif. Hasil yang diperoleh dari penelitian ini adalah strategi latihan pola ritme yang disesuaikan dengan tanda sukat yang ada pada materi yang berupa lagu yang akan dilatih dengan instrumen gitar.
\end{abstract}

Kata kunci: Pola ritme; pelatihan; pembelajaran; gitar

\section{Pengantar}

Dalam rangka pengembangan dan peningkatkan mutu pendidikan tinggi maka selayaknya segala usaha dan strategi harus dilakukan secara sinergi dan berkelanjutan. Usaha peningkatan mutu yang dilakukan berupa revisi kurikulum, pengadaan dan pemeliharaan infrastruktur, penambahan dosen dan kariawan, perbaikan sistem keuangan, dan sistem basis data yang terkoneksi dan sinergi satu sama lain. Usaha peningkatan jaminan mutu bisa dilakukan dari semua bidang tersebut di atas. Misalnya dalam bidang kurikulum, usaha bisa dilakukan dengan melakukan riset-riset, baik kurikulum, silabus, RPS, metode pembelajaran, dan strategi pembelajaran.

Dalam bidang musik, dua tahun terahir, usaha peningkatan mutu sudah dilakuakan dengan beberapa riset, diantaranya penelitain fundamental yang berjudul Perancangan Adaptasi Repertoar Konserto Untuk Ensembel Gitar Klasik Proses Pembelajaran Matakuliah Ensembel Pada Program Sarjana Seni (2014-2015) oleh Andre Indrawan dan Kustap. Penelitian ini 
menghasil repertoar dan diterapkan dalam pembelajaran mata kuliah ensembel gitar. Selain itu, penelitian berjudul Body Percussion Sebagai Model Pembelajaran Pada Mata Kuliah Metode Kelas Perkusi (2016) yang dilakukan oleh Ayub Prasetiyo dan Muh. Idham Kholid yang menghasilkan model pembelajaran perkusi dan diterapkan dalam kelas metode kelas perkusi.

Penelitian yang diajukan berikut ini merupakan usaha peningkatan jaminan mutu berkelanjutan yang mendukung pembelajaran mata kuliah instrumen gitar, dengan judul penelitian Pelatihan Pola Ritme Sebagai Strategi Peningkatan Kualitas Pembelajaran Mata Kuliah Instrumen Gitar di Jurusan Musik FSP ISI Yogyakarta oleh Kustap (dosen) dan Ikhsan Lubis (mahasiswa). Penelitian ini akan menyelidiki pola ritme (rhythm patterns) materi kuliah instrumen gitar dan strategi yang digunakan dalam proses pembelajarannya. Pola ritme dalam bermain musik, baik sebagai pemain instrumen, maumpun vocal serta konduktor, merupakan elemen musikal yang sangat penting dan utama dari elemen harmoni dan melodi. Pola ritme dalam pembelajaran gitar klasik sangat kompleks, di mana masingmasing jalur baik elemen harmoni maupun melodi berada pada jalur paranada yang sama, untuk itu perlu perhatian secara khusus, fokus dan sistemik. Pola ritme dalam harmoni harus diidentifikasi terlebih dahulu dan selanjutnya mengidentifikasi pola ritme pada jalur melodi. Pola rime harmoni maupun melodi pada gitar klasik mayoritas dilakukan atau dimaikan oleh gerakan jari kanan yaitu: jari pulgar/p (jempol), indiche/i (telunjuk), medio/m (tengah), dan jari anular/a (manis) atau disingkat $\mathrm{p}$ i $\mathrm{m}$ a.

Berdasarkan uraian latar belakang di atas, maka dapat dirumuskan dua permasalahan penting, yaitu: (1) bagaimana proses latihan pola ritme pada mata kuliah instrumen gitar? dan (2) apakah latihan dengan pola ritme memberikan dampak pada proses pembelajaran dan musikal mahasiswa. Proses latiahan pola ritme dilakukan dengan langkah menuliskan pola ritme dari lagu yang akan dilatih yang terletah diatas jalur paranada lagu tersebut. Pelatihan dimulai dengan pemahaman secara teoritis tentang sukat lagu tersebut, kemudian mulai mempraktikan pola rime dengan penjarian $p, i, m$, a pada empat birama pertama dengan pengulanganpengulangan hingga terasa lancar dan tidak ada kesalahan ritme. Selanjutnya, memeriksa dan melatih pola ritme pada seitiap birama dan jika ada perubahan pola rima maka akan dilakukan pelatihan berulang-ulang pada birama tersebut.

Hasil penelitian ini diharapkan akan melengkapi silabus bahan praktikum instrumen mayor gitar yang sudah ada dengan urutan seperti berikut ini: (1) Teknik (tangga nada, arpeggio, slur, dan sight reading), (2) Etude dan (3) Lagu-lagu (Renaisans/Barok, Klasik/Romanti, dan Modern), sedangakan Pola ritme akan dimasukan pada urutan pertama pada kelompok bahan praktikum teknik, maka urutan akan menjadi: (1) Teknik (pola ritme, tangga nada, arpeggio, slur, dan sight reading), (2) Etude dan (3) Lagu-lagu (Renaisans/Barok, Klasik/Romanti, dan Modern).

Penelitian yang dilakukan oleh A. Gathut Bintarto T., yang berjudul Strategi pengolahan materi musikal dan Teknis Paduan Suara: Studi Kasus Pengalaman Aktivitas Pentas, Lomba, dan Penjurian. Penelitian ini berkesimpulan bahwa strategi penunjang untuk mencapai kesuksesan paduan suara adalah: (1) adanya sebuah jadwal kegiatan yang jelas, mempersiapkan berbagai kemungkinan perencanaan, (3) antisipasi terhadap dinamika kelompok, (4) control perkembangan kegiatan, (5) pengamatan terhadap kegiatan apresiatif secara langsung. Selanjutnya disebutkan bahwah langkah- 
langkah yang dapat dilakukan agar hasil paduan suara menjadi optimal adalah: (1) melakukan screening awal melalui audisi ambitus, baca notasi, dan kemampuan beradaptasi, (2) pemetaan kekuatan dengan melihat rentang usia, aktivitas bermusik, pengaturan waktu, dan kondisi psikologis, (3) mengenal potensi diri, (4) merumuskan dasar pijakan.

Dari hasil penelitian tersebut di atas disebutkan bahwa strategi pengolahan musikal dan teknis sangatlah diperlukan untuk meningkatkat kemampuan musikal dan mencapai penampilan akhir yang optimal.

Sejalan dengan hasil penelian tersebut di atas maka penelitian berikut ini dapat melengkapi dan menambah wawasan dalam sudut pangdang dan materi instrumen yang berbeda. Penelitian berikut ini akan fokus pada pelatihan pola ritme untuk instrumen gitar.

Penelitian yang dilakukan oleh Andre Indrawan pada tahun 1998 yang berjudul Upaya Peningkatan Kualitas Studi Gitar Pada Jenjang Studi D3 dan S1 Melalu Tugas akhir Resital menunjukan hasil yang member kesimpulan sebagai berikut:

Bahwa jenjang S1 untuk program dtudi seni musik dalam pendidi-kan di Indonesiai jika dibandikan dengan pendidikan di luar negeri tampaknya mirip dengan BA (Hons) dalam bidang musik. Sementara itu public recital sebagai sarana pengembangan kualitas studi gitar dalam pendidikan tinggi di Indonesia yang pernah dilakukan ialah dalam rangka penyelesaian jenjang studi S1 Sarjana Musik (SMus) untuk Program Studi Sastra Musik (Musikologi), yang sebenarnya mirip dengan jenjang BMus (Hons) pada universitasuniversitas di Australia dan Amerika (Indrawan, 1998: 68-69).

Upaya yang dilakukan Indrawan tersebut di atas adalah salah satu strategi untuk meningkan mutu atau kualitas pembelajaran gitar di perguruan tinggi, melalui tugas akhir resital. Sejalan dengan itu penelitian berikut ini juga merupakan upaya peningkatan kualitas pembelajaran dalam perspektif yang berbeda yaitu pelatihan pola ritme dalam proses pembelajaran gitar.

Penelitian oleh Andre Indrawan dan Kustap, tahun 2014-2015 yang dimuat dalam jurnal Resital dengan judul Adaptasi Konserto pada Ensambel Gitar sebagai Upaya Pengayaan Bahan Ajar Matakuliah Ensambel menghasilkan kesimpulan seperti berikut:

dari segi produksi suara dan karakteristik produksi musikal gitar memiliki kesamaan dengan piano yang tidak dapat dipungkiri kondisinya. Meskipun demikian gitar memiliki kelemahan dibandingkan dengan piano dalam hal volume dan register. Jika dibandingkan dengan kelompok instrumen gesek (biola, viola, dan cello), gitar terdapat pada kelompok alat musik yang sama yaitu string, sementara piano berdiri sendiri. Dengan kelemahan dan kelebihannya, pada dasarnya gitar dalam formasi ensambel memiliki kelebihan dalam hal harmoni dan memainkan bagian-bagian orkestra secara lebih komprehensif yang tidak mungkin dapat dilakukan oleh piano. Dengan demikian sebuah ensambel gitar yang dirancang sedemikian rupa mampu mendekati penyajian orkestra dibandingkan dengan piano (Indrawan, 2015: 101).

Upapaya yang dilakukan dalam penelitian tersebut di atas adalah salah satu strategi peningkatan kualitas dalam hal pengayaan repertoar ensembel gitar. Betolak dari kesimpulan dan hasil penelitian tersebut, maka penelitian pelatihan pola ritme berikut ini merupakan salah satu strategi untuk meningkatkan kualitas musikal dan keteramilan para mahasiswa gitar di lingkungan ISI Yogyakarta.

Machlis (1963: 20) menyebutkan bahwa ritme merupakan pengontrol gerakan musik dalam waktu. Ia menyebutkan juga bahwa ritme adalah prinsip organisasi yang teratur dari panjang pendeknya nada-nada. Sedangkan definisi yang berorientasi fungsi yang dikemukakan oleh Paul Creston (1963) 
dalam Rossi (1963: 697) bahwa untuk memulai membuat sebuah komposisi musik, yang pertama-tama dilakukannya adalah membuat ritme. Creston menekankan bahwa betapa penting belajar dan mengajarkan ritme dalam musik. Ritme sama pentingnya dengan mempelajari harmoni, melodi, kontrapung, dan bentuk musik.

Jones (1974: 11) menyebutkan bahwa ritme lebih memperhatikan masalah durasi atau panjang waktu dari bunyi-bunyi secara individual, untuk panjang waktu disimbolkan dengan notasi nada-nada, sedangakan waktu diam disimbolkan dengan tanda istirahat atau rest. Sedang Kreter (1976) dalam bukunya Sight and Sound A manual of Aural Musicianship menempatkan meter dan ritme pada proses pembelajarjaran awal solfegio. Seorang ahli musik Kreter mengatakan rhythm and meter are the most basic arganizing elements in music, ritme dan sukat adalah organisasi elemen-elemen musik yang sangat mendasar (Kreter, 1976: 1).

Selanjutnya Scholes (1978: 481-482) melengakapi pendapat Jones dengan menyebutkan bahwa ritme adalah segala sesuatu yang melingkupi sisi waktu dalam musik di mana unsur yang termasuk dalam ritme adalah efek-efek dari beat, aksen, bar, kelompok nada-nada dalam beat, kelompok beat dalam bar, dan kelompok bar dalam pharase. Lebih lanjut, hasil penelitian tentang ritme musik yang dilakukan Dorrell (2005: 178), menegaskan bahwa persepsi manusia terhadap ritme didasarkan atas beat yang teratur, di mana beat didefinisikan sebagai bunyi-bunyi konstan yang diulang-ulang pada interval yang tepat.

\section{Metode}

Jenis penelitian yang digunakan dalam penelitian ini adalah kualitatif dengan pendekatan studi kasus. Studi kasus merupakan strategi penelitian dimana di dalamnya peneliti menyelidiki secara cermat suatu program, peristiwa, aktifitas, proses atau sekelompok individu. Kasus-kasus dibatasi oleh waktu dan aktifitas, dan peneliti mengumpulkan informasi secara lengkap dengan menggunakan berbagai prosedur pengumpulan data berdasarkan waktu yang telah ditentukan (Stake, 1995) dalam Creswell (2014: 20).

Situasi sosial atau subjek penelitian adalah semua mahasiswa di kelas ensembel gitar dan kelas instrument gitar pada Jurusan Musik semester gasal tahun ajaran 2017-2018. Jumlah mahasiswa sebagai reponden atau partisipan 21 orang mahasiswa ensembel gitar, 6 mahasiswa instrumen gitar II, 2 orang Instrumen gitar III, dan 1 mahasiswa intrumen gitar $\mathrm{V}$, dengan tidak membedakan jenis kelamin. Metode pengumpulan data dilakukan dengan wawancara untuk mendapatkan atau memverifikasi data berdasarkan observasi. Peneliti terlibat langsung atau dikenal dengan istileh participant observation yaitu pengumpulan data yang digunakan untuk menghimpun data penelitian melalui pengamatan dan pengindraan dimana peneliti benar-benar terlibat dalam kegiatan responden. Instrumen penelitian yang digunakan oleh peneliti dalam hal ini adalah instrumen pokok dan instrumen penunjang. Instrumen pokok dalam penelitian ini adalah peneliti sendiri, sedangkan instrumen penunjang adalah pedoman observasi dan pedoman wawancara.

Analisis data dilakukan dengan model interaktif, yang dilakukan melalui reduksi data. Reduksi data di sini bukan berarti penyederhanaan yang mengurangi kualitas data, akan tetapi sebaliknya, yakni bertujuan untuk meningkatkan data sehingga kompilasi data yang semula belum teratur dapat disusun kembali ke dalam bentuk baru. Reduksi data dilakukan dengan mengklasifikasikan data sehingga masingmasing data dapat dianalisis sesuai dengan tujuan penelitian. Setelah melalui tahap 
reduksi, langkah selanjutnya adalah penyajian data berdasarkan proses interpretasi dan triangulasi menuju hasil kesimpulan penelitian.

\section{Pembahasan}

Hasil yang sudah dicapai hingga laporan kemajuan penelitian ini adalah berupa pola ritme yang diambil dari etude ataupun lagu yang yang sudah ada dalam buku diaplikasikan dalam proses pembelajaran mata kuliah gitar 1, gitar 3, dan gitar 5 .

\section{Materi Pembelaran Gitar 1}

Materi pembelajaran yang digunakan dalam pelatihan pola ritme untuk mahasiswa yang mengambil mata kuliah gitar 1 diambil dari salah satu lagu yang terdapat dalam buku bahan praktikum gitar 1 halaman 34 atau List B No. 3 halaman 13 dalam buku Gitar AMEB (Autralian Musics Examinations Boards). Bahan yang diambil sebagai contoh dalam penelitian ini berjudul Barcarolle karya Napoleon Coste (1806-1883) seorang komposer dan gitaris dari Francis. Judul karya ini berasal dari Recreation du guitarite Op. 51, No. 1. Karya ini ditulis dalam sukat (meter) 3/8 dalam tangga nada $3 \#$ atau $\mathrm{A}$ mayor dengan jumlah birama sama dengan 32 bar.

\section{Pelatihan Pola Ritme Gitar 1}

Pembelajaran dimulai dengan mengamati dan memahami sukat pada lagu Barcarolle seperti yang tertulis pada urutan kedua setelah tanda mula, yaitu sukat $3 / 8$ (tiga per delapan). Sebelum menemukan pola ritme terlebih dalu mendefinisikan pengertian tentang sukat. Formula sukat $\mathrm{x}=\mathrm{a} / \mathrm{b}$, di mana $\mathrm{x}$ adalah satu birama, a adalah jumlah hitungan atau ketukan dalam satu birama (x), dan tanda / berarti per atau bagi, $\mathrm{dan} b$ adalah nilai hitungan atau ketukan. Nilai perketukan $b$ atau setiap ketukan $b$ sama dengan $\mathrm{x} / \mathrm{a}$ atau $(\mathrm{a} / \mathrm{b}) / \mathrm{a}$ atau sama dengan $1 / b$.

Dari definisi tersebut maka sukat $3 / 8$ dapat diartikan satu birama sama dengan 3 ketukan dan stiap ketukan bernilai (3/8)/3 sama dengan 1/8 ketukan, atau satu birama sama dengan 3 ketukan dan setiap ketukan benilai $1 / 8$ ketukan, atau satu birama sama dengan $1=3 \times(1 / 8)=3 / 8$. Selanjutnya melatih pola ritme dengan pikiran sambil menghitung atau membaca notasi, memainkan dengan gitar serta mendengar atau merasakan pola ritme.

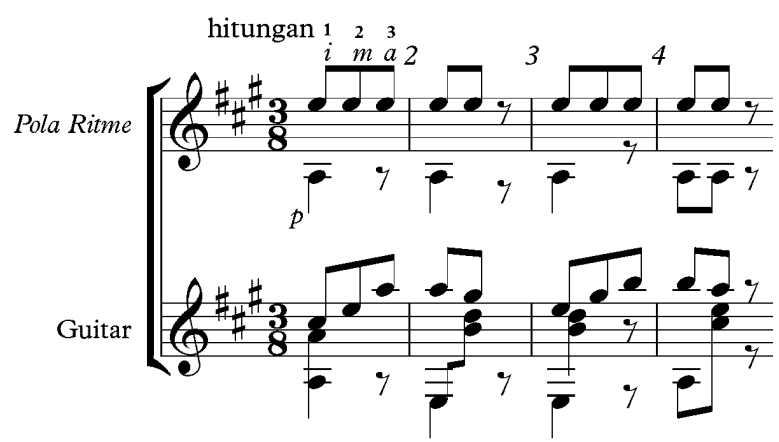

Gambar 1. Pola Ritme pada Lagu Barcarolle karya Napoleon Coste (1806-1883)

Kendala yang dihadapi mahasiswa peserta matakuliah Instrumen gitar 1 pada lagu Barcarolle, terlihat pada pola ritme birama 32, kesalahan selalu terjadi pada hitungan ke tiga dengan ritme hitungan seperenambelas. Hal ini terjadi disebabkan muhasiswa sudah hafal dengan melodi, sementar ritme diabaikan. Hal ini diatasi dengan cara mahasiswa melatih pola ritme pada birama 32 secara berulang-ulang.

Materi Pembelaran Gitar 3

Materi pembelajaran yang digunakan dalam pelatihan pola ritme untuk mahasiswa yang mengambil mata kuliah gitar 3 diambil dari salah satu lagu yang terdapat dalam buku bahan praktikum gitar 3 halaman 27 berjudul Bourree karya Johann Sebastian Bach (1685-1750) seorang komposer Jerman. Karya ini diambil dari karya Lute Suite No. 1. ditulis dalam sukat (meter) 4/4 dalam tangga nada 1 \# atau $G$ mayor dengan jumlah birama 26 bar.

Pelatihan Pola Ritme Gitar 3

Sukat 4/4 dapat diartikan satu birama sama dengan 4 ketukan dan stiap ketukan 
bernilai (4/4)/4 sama dengan $1 / 4$ ketukan, atau satu birama sama dengan 4 ketukan dan setiap ketukan benilai $1 / 4$ ketukan, atau satu birama sama dengan $1=4 \times(1 / 4)=4 / 4$. Selanjutnya melatih pola ritme dengan pikiran yaitu menghitung atau membaca notasi, memainkan dengan gitar serta mendengar atau merasakan pola ritme.

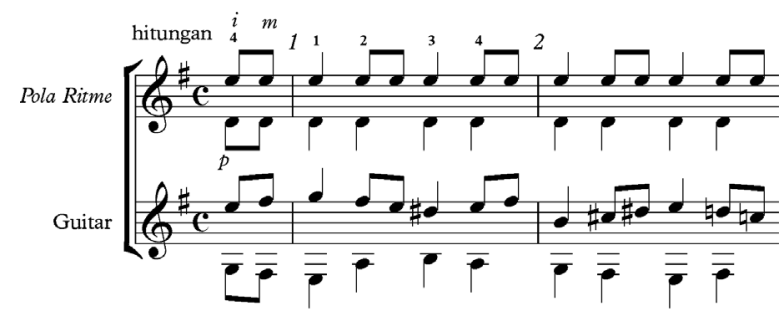

Gambar 2. Pola Ritme pada Lagu Bourree karya Johann Sebastian Bach (1685-1750)

Kendala yang dihadapi mahasiswa peserta matakuliah Instrumen gitar 3 pada lagu Bourree, terlihat pada pola ritme birama 17 dan 21, kesulitan terjadi pada proses membedakan hitungan ritme jalur melodi atas dengan melodi bawah. Hal ini terjadi disebabkan mahasiswa sudah hafal ritme jalur melodi atas, sementar ritme melodi jalur bawah (bass) belum dikuasai dengan baik. Hal ini diatasi dengan cara, mahasiswa melatih pola ritme pada masing jalur baik jalur melodi atas maupun bawah dengan tempo lambat.

Materi Pembelajaran Gitar 5

Materi pembelajaran yang digunakan dalam pelatihan pola ritme untuk mahasiswa yang mengambil mata kuliah gitar 5 diambil dari salah satu lagu yang terdapat dalam buku bahan praktikum gitar 5 halaman 49-52 berjudul Suite Populaire Bresilienne No. II. Schottish Choro karya Heitor Villa-Lobos (1887-1959) seorang komposer dari Amerika Selatan. Karya ini ditulis dalam sukat (meter) 2/4 dalam tangga nada $4 \#$ atau $E$ mayor dengan jumlah birama 113 bar.

Pelatihan Pola Ritme Gitar 5

Sukat 2/4 dapat diartikan satu birama sama dengan 2 ketukan dan stiap ketukan bernilai (2/4)/2 sama dengan 1/4 ketukan, atau satu birama sama dengan 2 ketukan dan setiap ketukan benilai $1 / 4$ ketukan, atau satu birama sama dengan $1=4 \times(1 / 4)=4 / 4$. Selanjutnya melatih pola ritme dengan pikiran yaitu menghitung atau membaca notasi, memainkan dengan gitar serta mendengar atau merasakan pola ritme.

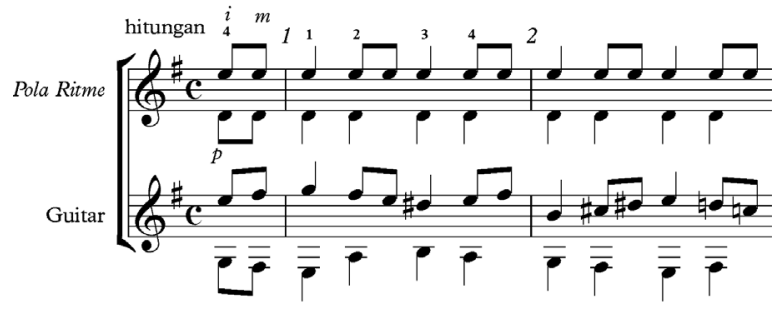

Gambar 2. Pola Ritme lagu No. II. Schottish Choro karya Heitor Villa-Lobos (1887-1959)

Kendala yang dihadapi mahasiswa peserta matakuliah Instrumen gitar 3 pada lagu Bourree, terlihat pada pola ritme birama 17 dan 21, kesulitan terjadi pada proses membedakan hitungan ritme jalur melodi atas dengan melodi bawah. Hal ini terjadi disebabkan mahasiswa sudah hafal ritme jalur melodi atas, sementar ritme melodi jalur bawah (bass) belum dikuasai dengan baik. Hal ini diatasi dengan cara, mahasiswa melatih pola ritme pada masing jalur baik jalur melodi atas maupun bawah dengan tempo lambat.

5. Materi Pembelajaran Gitar 5

Materi pembelajaran yang digunakan dalam pelatihan pola ritme untuk mahasiswa yang mengambil mata kuliah gitar 5 diambil dari salah satu lagu yang terdapat dalam buku bahan praktikum gitar 5 halaman 49-52 berjudul Suite Populaire Bresilienne No. II. Schottish Choro karya Heitor Villa-Lobos (1887-1959) seorang komposer dari Amerika Selatan. Karya ini ditulis dalam sukat (meter) 2/4 dalam tangga nada 4\# atau E mayor dengan jumlah birama 113 bar.

6. Pelatihan Pola Ritme Gitar 5

Sukat 2/4 dapat diartikan satu birama sama dengan 2 ketukan dan stiap ketukan bernilai (2/4)/2 sama dengan 1/4 ketukan, 
atau satu birama sama dengan 2 ketukan dan setiap ketukan benilai $1 / 4$ ketukan, atau satu birama sama dengan $1=4 \times(1 / 4)=4 / 4$. Selanjutnya melatih pola ritme dengan pikiran yaitu menghitung atau membaca notasi, memainkan dengan gitar serta mendengar atau merasakan pola ritme.

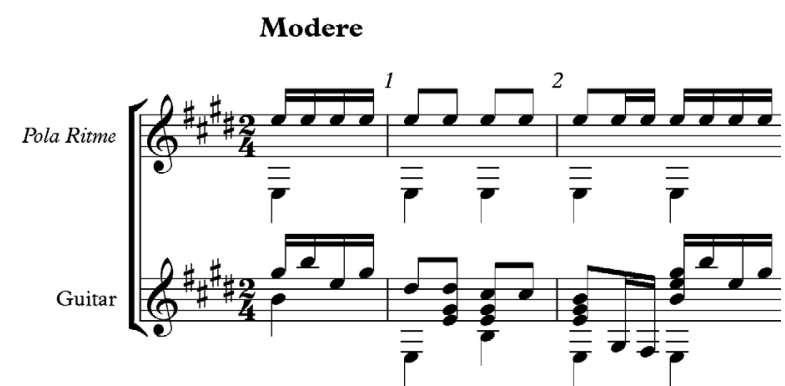

Gambar 2. Pola Ritme lagu No. II. Schottish Choro karya Heitor Villa-Lobos (1887-1959)

Kendala yang dihadapi mahasiswa peserta matakuliah Instrumen gitar 5 pada lagu Schottish Choro, terlihat pada pola ritme birama 2, kesulitan terjadi pada proses membedakan hitungan ritme jalur melodi atas dengan melodi bawah. Hal ini terjadi disebabkan posisi penjarian melodi atas yang menggunakan jari $\mathrm{p}$, sementara jalur bass juga menggunakan jari p. Hal ini diatasi dengan cara, mahasiswa melatih jari jari $p$ pada pola ritme jalur melodi atas maupun bawah dengan dari tempo lambat dan semakin cepat.

\section{Pengamatan Terhadap Responden}

Pengamatan tehadap proses pembelajaran dilakukan dengan cara cek list lembar pengamatan, ada 2 lebar pengamatan: (1) pengamatan nilai UTS pada table 1, dan (2) pengamatan proses pembelajaran pada table 3. Berikut ini penyajian pengamatan tabel 1 :

Tabel 1. Pengamatan Nilai UTS Mahasiswa

\begin{tabular}{|c|c|c|c|c|}
\hline No & Nama Mahasiswa & Instrumen/Gitar & Kehadiran & Nilai TTS \\
\hline 1. & I Made Danajaya & Menengah I/1 & 8 & $90 / \mathrm{A}$ \\
\hline 2. & Aditya Yudha Prasetyo & Menengah I/1 & 8 & $92 / \mathrm{A}$ \\
\hline 3. & Alfando Nugroho Saputro & Menengah I/1 & 8 & $92 / \mathrm{A}$ \\
\hline 4. & Titus Gesang Lokewara & Menengah I/1 & 8 & $90 / \mathrm{A}$ \\
\hline 5. & Reyhan Ardisola Cesa & Menengah I/1 & 8 & $86 / \mathrm{B}$ \\
\hline 6. & Eva Julia Wijanarko & Menengah I/1 & 8 & $90 / \mathrm{A}$ \\
\hline 7. & Muhammad Syukron I. A. & Menengah III/3 & 8 & 91/A \\
\hline 8. & Bimo Haryo Nugro & Menengah III/3 & 8 & $91 / \mathrm{A}$ \\
\hline 9. & Hizkia & Lanjut II/5 & 5 & $92 / \mathrm{A}$ \\
\hline
\end{tabular}

Tabel 2. Skor Nilai Materi UTS

\begin{tabular}{|r|l|c|}
\hline No. & \multicolumn{1}{|c|}{ Materi TTS Sesuai Tingkat } & Skor \\
\hline 1. & Pola Ritme lagu (sesuai tingkatnya) & 50 \\
\hline 2. & Tangga Nada & 10 \\
\hline 3. & Slur dari, Dick Visser & 10 \\
\hline 4. & Petikan Op. 1a, M. Giuliani & 10 \\
\hline 5. & Arpegio & 10 \\
\hline 6. & Kehadiran & 10 \\
\hline
\end{tabular}

Proses hasil pembelajara diamati dari tabel 1. dengan mengcek pada kolom data kehadiran dibandingkan dengan nilai TTS. Data kehadiran diambil daftar hadir kuliah semester gasal 2017/2018. Ada 6 (enam) mahsiswa Gitar Menengah I dan 2 (dua) mahasiswa Gitar Menengah III yang selalu hadir dalam delapan (8) kali pertemuan atau perkuliahan, sedangkan 1 (satu) mahasiswa Gitar Lanjit II hanya hadir lima (5) kali pertemuan. Nilai diambil dari TTS (tes tengah semester) yang diselenggarakan pada pertemuan ke delapan (8) dengan jadwal kuliah masing-masing kelas.

Jadwal kuliah: Gitar Menengah I dua mahasiswa, (Prodi Seni Musik) pada hari jumat jam 13.00, Gitar Menengah I empat mahasiswa (Prodi Pendidikan Musik) pada hari rabu jam 13.00, Gitar Menengah III dua mahasiswa (Seni Musik) pada hari senin jam 13.00, dan Gitar Lanjut II satu mahsiswa (Seni Musik) pada hari selasa jam 13,00.

Nilai yang dihasilkan: secara keseluruhan baik dengan nilai rata kelas 814/9=90,88 maka dapat diasumsikan bahwa nilai rata-rata kelas sanagat baik dengan gradasi skor nilai masing-masing poin dari materi TTS. Tampak pada Tabel 2 nilai pola ritme diberi angka 50 yang menunjukan bahwa nilai pola ritme adalah $50 \%$ dari keseluruhan nilai yang berjumlah 100 .

Tabel 3. Pengamatan Proses Latihan Gitar 1,

$$
3,5
$$

\begin{tabular}{|c|c|c|c|c|c|}
\hline \multirow{2}{*}{ No. } & \multirow{2}{*}{ Objek yang diamati } & $\mathrm{A}$ & B & $\mathrm{C}$ & $\mathrm{D}$ \\
\hline & & \multicolumn{4}{|c|}{ Jumlah pemilih } \\
\hline 1. & $\begin{array}{l}\text { Keseriusan mahasiswa dalam } \\
\text { memperhatikan penjelasan. }\end{array}$ & - & - & 1 & 8 \\
\hline 2. & $\begin{array}{l}\text { Keseriusan mahasiswa mengamati pola } \\
\text { ritme }\end{array}$ & - & _- & 1 & 8 \\
\hline 3. & $\begin{array}{l}\text { Keseriusan mahasiswa dalam berlatih } \\
\text { pola ritme }\end{array}$ & - & - & - & 9 \\
\hline 4. & $\begin{array}{l}\text { Melakukan diskusi pola ritme dengan } \\
\text { sesama mahasiswa }\end{array}$ & _- & - & 1 & 8 \\
\hline 5. & $\begin{array}{l}\text { Melakukan diskusi pola ritme dengan } \\
\text { dosen }\end{array}$ & _- & _- & 1 & 8 \\
\hline
\end{tabular}


Pengamatan proses dalam kelas pelatihan ritme dapat dihat hasil pada table 3, yang menunjukan kecendrungan mahsiswa adalah $\mathrm{C}$ dan $\mathrm{D}$, di mana $\mathrm{C}$ adalah semangat dan $\mathrm{D}$ adalah semangat dan serius. Pada urutan 1 keseriusan mahasiswa dalam memperhatikan penjelasan tentang pola ritme menunjukan 1 mahasiswa yang semangat sedangkan 8 mahasiswa lainnya sangat semangat. Urutan ke 2 hasilnya sama dengan urutan ke 1 . Urutan ke 3 menunjukan semua peserta 9 (Sembilan) mahasiswa memiliki semangat tinggi (D). Urutan ke 4, ada 1 mahasiswa yang semangat dan 8 lainnya semangat dan serius (D). Urutan ke 5, hanya 1 mahasiswa yang semangat sedangkan 8 lainnya semangat dan serius (D). Dari petunjuk table 3 di atas dapat dirangkum bahwa kira-kira 90\% mahasiswa memiliki semangat yang tinggi (D) dalam berlatih pola ritme, dan kurang lebih $20 \%$ hanya semangat (D). Maka dari table 1 dan 3 dapat dilihat bahwa nilai yang sanagt baik didukung oleh semangat yang tinggi dalam belajar atau berlatih pola ritme.

8. Hasil Pelatihan

Proses pembelajaran pola ritme dimulai dari pemahaman, penjelasan dan diskusi tentang sukat. Sukat atau dalam bahasa Inggris diartikan sebagai meter, atau disebut juga sebagai time signature, misalnya meter 4/4, 2/4,3/8. Meter dipahami sebagai proses sukat itu sendiri, yang di dalamnya terkandung unsur-unsur musik yang disebut beat. Pemahan meter dan beat dijelaskan dengan rumus $x=(a / b) / a$, di mana $x$ adalah birama 1, a adalah jumlah ketukan per birama, dan $b$ adalah nilai ketukan itu sendiri atau nilai persatuan hitungan sama dengan 1/b ketukan.

Proses latihan pola ritme pada setiap materi lagu atau masing-masing lagu dimulai dengan: (a) melihat tanda sukat termasuk jika ada perubahan sukat, (b) memahami nilai sukat $\mathrm{x}=(\mathrm{a} / \mathrm{b})$ dan $\mathrm{b}=\mathrm{x} / \mathrm{a}$ atau $\mathrm{b}=(\mathrm{a} / \mathrm{b}) / \mathrm{a}=1 / \mathrm{b}$ adalah nilai setiap hitungan atau ketukan, (c) membaca transkrip pola ritme dengan gitar pada jalur para nada pola ritme, (d) mengamati tanda mula atau tonika dan melatih tangga nada tersebut, (e) menerapkan pola rime pada jalur paranada gitar sesuai tanda mula.

\section{Penutup}

Proses pelatihan pola ritme dimulai dengan cara: memperhatikan sukat, memahmi nilai sukat, mengidentifikasi pola ritme, membaca transkrip pada jalur pola ritme, memperhatikan tanda mula atau tonika pada jalur para nada lagu, melatih tangga nada sesuai tanda mula pada lagu, selanjutnya menerapkan pola rime pada jalur paranada gitar sesuai dengan tanda mula diawali dengan tempo lambat berlanjut hingga tempo sebenarna.

Dapak berlatih pola ritme cendrung meningkatkan kemampuan rasa musikal, efesiensi latihan, dan meningkatkan skor nilai ujian. Rasa musikal diawali dari detak ritme kehidupan, lalu menuju ungkapan perasaan dalam melodi, dan dilengkapi dengan harmoni dalam jiwa. Latihan yang efisien akan meningkatkan produktifitas kemampuan fisik, meningkatnya jumlah penguasaan materi kuliah, dan akhirnya dapat menghasilkan skor nilai ujian akhir semester yang maksimal..

\section{Referensi}

Arnold, Jay, [1972]. Carcassi Clasical Guitar Method, California Music Press, Miami Beach, Fla.

Arikunto, Suharsimi, Suhardjono dan Supardi, [2016]. Penelitian Tindakan Kelas, Bumi Asara, Jakarta.

Bakan, Michael B., [2012]. World Music: Tradition And Transformations, second edition, McGraw Hill Componies. 
Creswell, John W, [2014]. Research Design Pendekatan Kualitatif, Kuantitatif dan Mixed, (penerjemah: Acmad Fawaid), Pustaka Pelajar, Yogyakarta.

Dewi, Octavia Rosiana, [2013], “Konsep Minimax Slamet Abdul Sjukur dalam Musik Uwek-Uwek", dalam Resital Jurnal of Performing Art, Volume 14 No. 2-Desember 2013.

Dorrell, Philip, [2005]. Whyat is Music, http://whatismusic.ifo/.

Gathut Bintarto T, A., [2015], "Strategi Pengelolaan Materi Musikal dan Teknis Paduan Suara (Studi Kasus Pengalaman Aktivitas, Pentas, Lomba, dan Penjurian)" dalam Promusika Jurnal Pengkajian, Penyajian, dan Penciptaan Musik, Volume 3 No. 2, Oktober 2015: 25-38. Griffiths, John (ed.), [1995], Guitar, AMEB, Allans Publishing Pty., Melbourne.

Indrawan, Andre, [1998]. “Upaya Peningkatan Kualitas Studi Gitar Pada Jenjang Studi D3 dan S1 Melalui Tugas Akhir Resital", (laporan hasil penelitian) LPM ISI Yogyakarta.

Indrawan, Andre (ed), [2005]. “Bahan Praktikum Etude dan Lagu Gitar 1 KB13011", Jurusan Musik FSP ISI Yogyakarta.

Indrawan, Andre (ed), [2005]. “Bahan Praktikum Etude dan Lagu Gitar 3 KB13013", Jurusan Musik FSP ISI Yogyakarta.

Indrawan, Andre (ed), [2005]. “Bahan Praktikum Etude dan Lagu Gitar 5 KB13015", Jurusan Musik FSP ISI Yogyakarta.

Indrawan, Andre dan Kustap, [2014], “Proses Pembelajaran Mata Kuliah Ensembel Pada Program Diploma dan Sarjana di Perguruan Tinggi Seni Indonesia", dalam Prosiding Seminar Nasional Festifal Kesenian Indonesia Ke-8, Spirit of The Fiture:
Art for Humanizing, BP ISI Yogyakarta: 147-160.

Indrawan, Andre dan Kustap, [2015]. "Adaptasi Konserto pada Ensambel Gitar sebagai Upaya Pengayaan Bahan Ajar Matakuliah Ensambel", dalam Jurnal Resital Vol. 16 No. 2, Agustus 2015: 95-103.

Jones, George Thaddeus, [1974]. Music Theory, Barnes and Noble Books, New York.

Kreter, Leo, [1976]. Sight \& Sound: A Manual Of Aural Musicianship Vol. 1, New Jersey: Prentice-Hall., Inc.

Kreter, Leo, [1976]. Sight \& Sound: A Manual Of Aural Musicianship Vol. 2, New Jersey: Prentice-Hall., Inc.

Machlis, Joseph, [1963]. The Enjoyment of Music, W.W. Norton and Company Inc, New York.

Prasetiyo, Ayub, dan Muh. Idham Kholid, [2016], Body Percussion Sebagai Model Pembelajaran Pada Mata Kuliah Metode Kelas Perkusi, Laporan Penelitian, ISI Yogyakarta.

Rossi, Nick and Rafferty, Sadie, [1963], Music

Through The Centuries, Boston Bruce Humphries.

Scholes, Percy A., [1978]. The Concise Oxford Dictionary Of Music, Oxford University Press, London.

Sugiyono, [2011]. Metode Penelitian Kuantitatif, Kualitatif dan R\&D, CV Alfabeta, Bandung.

Summerfield, Maurice J., [2002]. The Classical Guitar Its Evolution, Players and Personalities Since 1800, Fifth Edition, Ashley Mark Publishing Gompany.

Toussaint, Godfried T., [2013], The Geometry of Musical Rhythm, what makes a "good" rhythm good?, CRC Press, New York. 